\title{
Detection of cellular senescence within human invasive breast carcinomas distinguishes different breast tumor subtypes
}

\author{
Cristina L. Cotarelo ${ }^{1}$, Arno Schad ${ }^{1}$, Charles James Kirkpatrick ${ }^{1}$, Jonathan P. \\ Sleeman ${ }^{2,3}$, Erik Springer ${ }^{1}$, Marcus Schmidt ${ }^{4}$, Sonja Thaler ${ }^{2}$ \\ ${ }^{1}$ Institute of Pathology, University Medical Center, Johannes Gutenberg University, Mainz, Germany \\ ${ }^{2}$ Centre for Biomedicine and Medical Technology Mannheim (CBTM), Medical Faculty Mannheim, University of Heidelberg, \\ Mannheim, Germany \\ ${ }^{3}$ KIT Campus Nord, Institute for Toxicology and Genetics, Karlsruhe, Germany \\ ${ }^{4}$ Department of Obstetrics and Gynecology, University Medical Center, Johannes Gutenberg University, Mainz, Germany \\ Correspondence to: Sonja Thaler, email: Sonja.Thaler@medma.uni-heidelberg.de, Sonja.Thaler@gmx.de
}

Keywords: cellular senescence, breast cancer subtypes, breast cancer pathology

Received: December 23, $2015 \quad$ Accepted: September 12, $2016 \quad$ Published: October 04, 2016

\section{ABSTRACT}

Oncogene-induced senescence is thought to act as a barrier to tumorigenesis by arresting cells at risk of malignant transformation. Nevertheless, numerous findings suggest that senescent cells may conversely promote tumor progression through the development of the senescence-associated secretome they produce. It is likely that the composition and the physiological consequences mediated by the senescence secretome are dependent on the oncogenes that trigger the senescence program. Breast cancer represents a heterogenous disease that can be divided into breast cancer subtypes due to different subsets of genetic and epigenetic abnormalities. As tumor initiation and progression of these breast cancer subtypes is triggered by diverse oncogenic stimuli, differences in the senescence secretomes within breast tumors might be responsible for tumor initiation, progression, metastasis and therapeutic response. Many studies have addressed the role of senescence as a barrier to tumor progression using murine xenograft models. However, few investigations have been performed to elucidate the degree to which senescent tumor cells are present within untreated human tumors, and if present, whether these senescent tumor cells may play a role in disease progression. In the present study we analysed the appearance of senescent cells within invasive breast cancers. Detection of cellular senescence by the use of SA $\beta$-galactosidase (SA $\beta-g a l)$ staining within invasive breast carcinoms from 129 untreated patients revealed differences in the amount of SAB-gal+ tumor cells between breast cancer subtypes. The highest percentages of SAB-gal+ tumor cells were found in HER2-positive and luminal A breast carcinomas whereas triple negative tumors showed either little or no positivity.

\section{INTRODUCTION}

Cellular senescence is considered to be a pivotal tumor-suppressor mechanism that prevents the outgrowth of oncogenically transformed cells through cell cycle arrest $[1,2]$. Oncogenes that have the potential to initiate and promote tumorigenesis generally provoke the induction of cellular senescence to counteract tumor formation. Therefore, a prerequisite for the oncogenic transformation of cells and the subsequent establishment of a lethal tumor is that the cells must circumvent oncogene-induced senescence, and gain the ability to proliferate while expressing activated oncogenes [3]. Studies based on human and murine tissues support the notion that cellular senescence can suppress carcinogenesis [4-9]. The ability of cells to induce the senescence program in response to oncogeneic stimuli depends mainly on the tumor suppressor pathways Arf-p53 and pRB-p16 ${ }^{\mathrm{INK} 4 \mathrm{a}}[10,1]$. Escape from senescence is thought to occur when senescent cells acquire additional genetic or epigenetic alterations that reverse their growth arrest. Thus defects in Arf-p53 and pRBp $16^{\mathrm{INK} 4 \mathrm{a}}$ circumvent the induction of senescence and enhance susceptibility to cancer progression $[11-13,6]$. 
Although escape from senescence is thought to be a central requirement for tumor initiation and progression, senescence can still be induced in tumor cells under certain circumstances [2]. Thus tumor cells may enter senescence in response to conventional anti-cancer therapies such as chemotherapy $[13,14]$, after reactivation of $\mathrm{p} 53[15,16]$ or through an Arf-p53-independent mechanism based on the loss of Skp2 [17]. In these cases, induction of senescence is associated with tumor regression and the initiation of an inflammatory response that stimulates immune cells to eliminate the senescent cells [16, 18, 19].

Senescent cells develop a senescence-associated secretory phenotype (SASP) in which a variety of factors termed the senescence messaging secretome (SMS) are secreted that can affect the behavior of neighboring and immune cells $[1,20]$. Many SASP components are protumorigenic growth factors, proteases or cytokines known to stimulate the aggressive behaviour of cancer cells in vitro [21-23]. In mouse xenografts, senescent cells have been shown to promote malignant progression of precancerous, as well as established cancer cells [24, 21]. Additionally, it was reported that the SASP of senescent cells transformed by constitutive HER2 signalling inhibits the clearance of senescent cells and exerts pro-metastatic effects leading to breast cancer progression [25].

Although the paracrine activities of SASP proteins can promote phenotypes associated with malignancy, the SASP is complex, and not all components are cancer promoting [1]. It is likely that each SASP factor may have effects that depend on the cell and tissue context [25]. Some SASP components are chemoattractive factors that mediate the clearance of senescent cells in vivo through attracting cells of the immune system $[16,18]$. In this context it is conceivable that recruitment of immune cells and the outcome of the immune response might be dependent on the composition of the senescence-associated secretome.

The function of senescence as a barrier to tumor progression and its role in tumor initiation and progression has been demonstrated in murine xenograft models $[24,22,25]$. However, the presence and relevance of senescent tumor cells in untreated human tumors has been little investigated. In the present study we investigated senescence-associated $\beta$-galactosidase (SA $\beta$-gal) activity within 129 breast cancer samples from patients who had not been treated with neoadjuvant therapy. We observed differences in the amount of SA $\beta$-gal positive tumor cells between and within breast cancer subtypes. The highest percentage of SA $\beta$-gal positive tumor cells was found in the HER2+ and luminal A breast cancer samples, whereas the vast majority of triple negative tumors displayed either very few or no SA $\beta$-gal positive tumor cells. As breast cancer subtypes differ in their driver mutations, and the induction of senescence can vary in response to differing oncogenic stimuli, the amount of SA $\beta$-gal positive tumor cells likely reflects differences in the ability of breast cancer subtypes to undergo senescence. Alternatively or in addition, the composition of the secretome released by senescent tumor cells from different breast cancer subtypes might be very distinct with respect to their ability to recruit immune cells that eliminate senescent cells, with the consequence that senescent cells might be removed efficiently by the immune system in some breast cancer subtypes, but not in others.

\section{RESULTS}

\section{Constitution of the patient sample collection}

Tumor tissue from 176 patients was collected. All patients were female and only 4 of them had a previous history of early breast cancer. To ensure that senescent cells within the tumors were not induced by previous treatments, such as chemo- or radiotherapy, all samples from neoadjuvantely treated patients were excluded from this study. The ages ranged from 32 to 84 years, with a median of 58.6 years. The other clinicopathological data are summarized in Table 1. Only 129 of the 176 cases were able to be used in this study as described in the Materials and Methods section. The tumor tissue of these 129 patients was classified according to the St. Gallen molecular subtypes. The division of this patient collective into the main molecular breast cancer subtypes is shown in Table 2.

\section{SA $\beta$-gal-positive tumor cells exist within invasive breast cancer samples}

Two consecutive frozen sections were generated from the human breast tumor tissue immediately after surgury (Figure 1). One section was used for intraoperative examination and diagnostic evaluation, whereas the second serial section was used for detection of SA $\beta$-gal activity (Figure 1B-1C). Homogeneous cytoplasmic staining with differences in the amount and intensity of SA $\beta$-gal staining was observed within the breast tumor samples (Figure $2 \mathrm{~A}$ a-d). The vast majority of SA $\beta$-gal positive cells could be clearly identified as tumor cells. However in some samples we were unable to observe SA $\beta$-gal positive tumor cells (Figure 2A a). These tumor samples together with samples in which only non-tumor cells were $\mathrm{SA} \beta$-gal positive were defined as SA $\beta$-gal negative. Patient samples in which marginal cytoplasmatic staining $(<50 \%$ of tumor cells) was observed were designated as SA $\beta$-gal low (Figure 2A b). Samples with strong cytoplasmatic staining of tumor cells ( $>50 \%$ of tumor cells) were defined as SA $\beta$-gal high (Figure 2A c-d).

\section{Detection of SA $\beta$-gal positive cells distinguishes different molecular breast cancer subtypes}

Next we investigated whether the appearance of SA $\beta$-gal positive tumor cells correlates with hormone 
Table 1: Relation of histological tumor type, histological grading and pT-stage of all 176 patients

\begin{tabular}{|l|c|c|c|c|c|}
\hline \multicolumn{3}{c}{ Histological Tumor Type } & \multicolumn{3}{c|}{ Histological Grading } \\
\hline Invasive ductal carcinoma & $114(64.8 \%)$ & G1 & $42(24.1 \%)$ & pT1a-c & $109(61.9 \%)$ \\
\hline Invasive lobular carcinoma & $30(17 \%)$ & G2 & $79(44.4 \%)$ & pT2 & $56(31.8 \%)$ \\
\hline Invasive mucinous carcinoma & $4(2.3 \%)$ & G3 & $53(30.4 \%)$ & pT3 & $9(5.1 \%)$ \\
\hline Invasive cribiform carcinoma & $2(1.1 \%)$ & & & pTis & $2(1.1 \%)$ \\
\hline Tubular carcinoma & $2(1.1 \%)$ & & & & \\
\hline Non invasive carcinoma & $2(1.1 \%)$ & & & & \\
\hline $\begin{array}{l}\text { Other types of invasive } \\
\text { carcinoma }\end{array}$ & $22(12.5 \%)$ & & & & \\
\hline
\end{tabular}

receptor expression and HER2 status. Interestingly, we observed the highest percentage of high SA $\beta$-gal positive tumor cells within HER2 positive patient samples $(87.5 \%)$ whereas the vast majority of triple negative breast cancer (TNBC) samples did not display any SA $\beta$-gal positive tumor cells $(88.9 \%$ ) (Table 3) (Figure 3C a-d). Luminal breast cancers also displayed high percentages of strongly SA $\beta$-gal positive tumor cells $(72.6 \%)$. However, differences were seen in the percentages of high, low $\mathrm{SA} \beta$-gal positive and $\mathrm{SA} \beta$-gal negative tumor cells between luminal A and luminal B tumors (Table 3 ) and between HER2+/ER+ and HER2+/ER - tumors (Table 3). Statistical analysis identified significant differences in the distribution of SA $\beta$-gal positive and SA $\beta$-gal negative tumor cells and in the distribution of SA $\beta$-gal positive and SA $\beta$-gal low/negative tumor cells among the molecular breast cancer subtypes (Table 4).

\section{SA $\beta$-gal positive tumor cells show inverse correlation with the proliferation marker Ki67}

Senescence cells are typified by cell cycle arrest and therefore SA $\beta$-gal-positive senescent cells should not proliferate. To demonstrate that SA $\beta$-gal positive cells are growth arrested, we aimed to analyse expression of the proliferation marker Ki67 within SA $\beta$-gal positive tumor cells. Double staining of immunohistochemical and SA $\beta$-gal staining was not possible due to incompatibility of the fixations required for the two stains. Therefore, to assess the proliferation status of SA $\beta$-gal positive tumor cells, we first quantified the percentages of Ki67 positive tumor cells within all 129 tumors using paraffin sections from a piece of tumor that corresponded exactly with the position in the tumor from which the frozen sections for SA $\beta$-gal staining had been taken. The percentages of Ki67
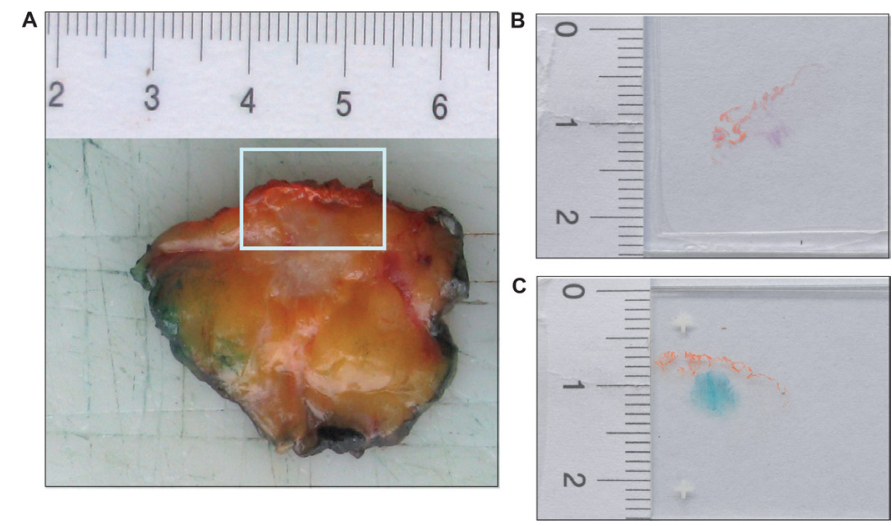

Figure 1: SA $\beta$-gal staining reveals the existence of senescent cells within breast cancer sections. (A) The frozen tissue of human breast tumours used in this study was collected immediately after an intraoperative diagnostic evaluation. Margins of the surgical specimen were marked with ink. Tumor with the next surgical margin was frozen. In this figure the next surgical margin was marked with orange ink. Two successive frozen sections were generated from tumor tissue immediately after surgury. (B) One frozen section was stained with eosin and hematoxilin (H\&E), using standard laboratory procedures, and intraoperative examined. (C) A second proximate section of the frozen breast tissue from each case was obtained and collected for detection of SA $\beta$-gal activity. SA $\beta$-gal staining reveals the existence of senescent cells within breast cancer sections. 
Table 2: Classification of the 129 patients samples used in this study according to the St. Gallen molecular breast cancer subtypes

\begin{tabular}{|c|c|c|c|c|c|c|c|c|}
\hline Molecular subtype & Luminal & $\begin{array}{c}\text { Luminal } \\
\mathbf{A}\end{array}$ & $\begin{array}{c}\text { Luminal } \\
\text { B }\end{array}$ & HER2+ & $\begin{array}{c}\text { ER+/ } \\
\text { HER2+ }\end{array}$ & $\begin{array}{c}\text { ER-/ } \\
\text { HER2+ }\end{array}$ & $\begin{array}{c}\text { Triple } \\
\text { neg. }\end{array}$ & Total cases \\
\hline Number of cases & 95 & 77 & 18 & 16 & 12 & 4 & 18 & 129 \\
\hline Number of cases $\%$ & 73.6 & 59.7 & 13.9 & 12.4 & 9.3 & 3.1 & 13.9 & 100 \\
\hline
\end{tabular}

positive tumor cells within all 129 patient samples were in a range from approximately 5 to $90 \%$. Separating the tumors into Ki67 low (Ki67 < 40\%) or high (Ki67> 40\%) revealed that the majority of the luminal and HER2 amplified patient samples had less then 40\% Ki67 (range 5-35\%), whereas approximately $90 \%$ of all triple negative patient samples had more than 40\% Ki67 (range 40-90\%) (Table 5). Patient samples that displayed high percentages of high SA $\beta$-gal positive cells had correspondingly low percentages of Ki67 positive cancer cells, and vice versa (Table 6). Statistical analysis revealed a statistically significant inverse correlation between SA $\beta$-gal positivity and Ki67 positivity, supporting the notion that senscent SA $\beta$-gal-positive tumor cells are cell cycle arrested.

\section{SA $\beta$-gal positivity inversely correlates with expression of the nuclear lamina protein Lamin B1}

Although SA $\beta$-gal expression is the most widely used marker to detect cellular senescence in vitro and in vivo, $\mathrm{SA} \beta$-gal positivity alone is not always a reliable indicator of whether cells are in the senescent state. Therefore we investigated whether SA $\beta$-gal expression correlates with loss of the nuclear lamina protein Lamin B1, which also serves as biomarker for senescent cell [2628]. As patient samples from triple negative and HER2+ breast tumors displayed the largest differences between high SA $\beta$-gal positive tumor cells (Table 3; Table 4; Figure
3 ), these samples were chosen to investigate potential differences in Lamin B1 expression. Immunohistochemical analysis revealed that $\mathrm{SA} \beta$-gal positivity inversely correlated with Lamin B1 expression in these samples (Figure 3; Figure 4; Table 7), supporting the notion that SA $\beta$-gal-positive tumor cells are indeed in the senescent state. Consistently, representative sections of luminal A tumors with a high proportion of SA $\beta$-gal positive cells also displayed no or only low numbers of Lamin B1 positive cells. Notably, normal luminal cells showed high expression of Lamin B1, whereas adjacent tumor cells expressed low or no Lamin B1 (Figure 4C-4D).

\section{Detection of p53, p16 ${ }^{\mathrm{INK} 4 \mathrm{a}}$ and p21 ${ }^{\mathrm{Cip1/Waf1}}$ within triple negative and HER2+ breast cancer samples}

The ability of cells to induce the senescence program depends pivotally on the tumor suppressor pathways Arf-p53 and pRB-p16 $6^{\text {INK4a }}[10,1]$. Loss of p53 or mutations in TP53 that turn p53 into an oncogene, as well as inhibition or loss of $\mathrm{pRB}$ and simultaneous overexpression of $\mathrm{p} 16^{\mathrm{INK} 4 \mathrm{a}}$ are associated with escape from senescence and an aggressive phenotype of breast cancer phenotype $[12,13,6,31,32]$. Although p $16^{\mathrm{INK} 4 \mathrm{a}}$ is increased in senescent cells and therefore is often used as a senescence marker, however $\mathrm{p} 16^{\mathrm{INK} 4 \mathrm{a}}$ can only stop proliferation of cells with a properly functioning $\mathrm{p} 16^{\mathrm{INK} 4 \mathrm{a}}$ pRB-pathway [32]. Thus, only in cells which still have

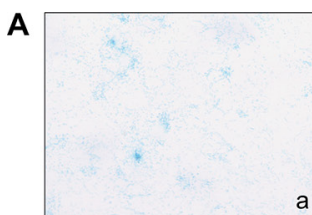

B

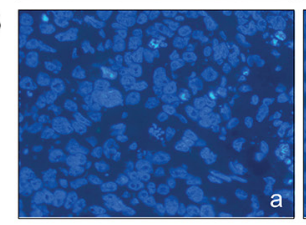

SA $\beta$-gal negative

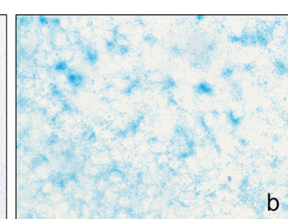

b

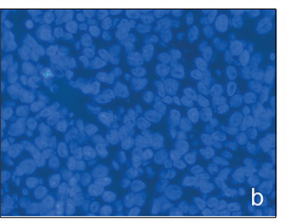

SAß-gal low positive
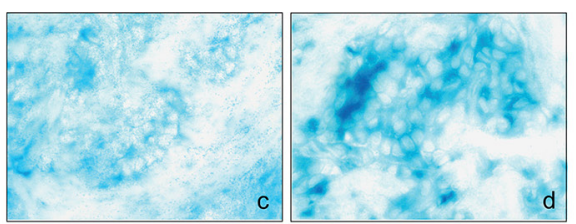

SAß-gal
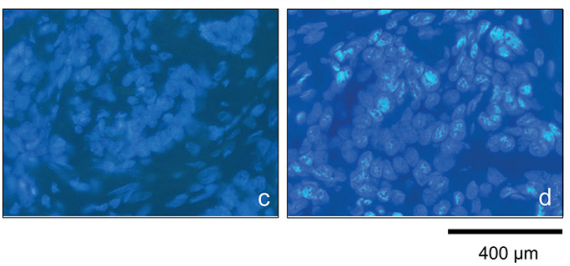

DAP

SAß-gal high positive

Figure 2: SA $\beta$-gal positive tumor cells exist within invasive breast cancer samples. (A) SA $\beta$-gal staining of the frozen human breast tumors sections, showing SA $\beta$-gal positive cells (a-d). Representative examples showing differences in the number of SA $\beta$-gal positive tumor cells in the different samples analysed. (a) SA $\beta$-gal negative; (b) SA $\beta$-gal low positive; (c) and (d) SA $\beta$-gal high positive. (B) (a-d) DAPI staining of sections shown in A (a-d). Bars: $400 \mu \mathrm{m}$. 
Table 3: Quantification of SA $\beta$-gal positive cells reveals different distribution patterns of SA $\beta$-gal positive cells within molecular breast cancer subtypes

\begin{tabular}{|c|c|c|c|c|c|c|c|c|}
\hline Molecular subtype & Luminal & $\begin{array}{c}\text { Luminal } \\
\text { A }\end{array}$ & $\begin{array}{c}\text { Luminal } \\
\text { B }\end{array}$ & HER2+ & $\begin{array}{c}\text { ER+/ } \\
\text { HER2+ }\end{array}$ & $\begin{array}{c}\text { ER-/ } \\
\text { HER2+ }\end{array}$ & $\begin{array}{c}\text { Triple } \\
\text { neg. }\end{array}$ & $\begin{array}{l}\text { Total } \\
\text { cases }\end{array}$ \\
\hline Number of cases & 95 & 77 & 18 & 16 & 12 & 4 & 18 & 129 \\
\hline SAß-gal high & $69(72.6 \%)$ & $58(75.3 \%)$ & $11(61.1 \%)$ & $14(87.5 \%)$ & $11(91.7 \%)$ & $3(75 \%)$ & $0(0 \%)$ & $83(64.3 \%)$ \\
\hline SA $\beta$-gal low & $22(23.1 \%)$ & $18(23.4 \%)$ & $4(22.2 \%)$ & $1(6.3 \%)$ & $1(8.3 \%)$ & $0(0 \%)$ & $2(11.1 \%)$ & $25(19.4 \%)$ \\
\hline SA $\beta$-gal negative & $4(4.2 \%)$ & $1(1.3 \%)$ & $3(16.7 \%)$ & $1(6.3 \%)$ & $0(0 \%)$ & $1(25 \%)$ & $16(88.9 \%)$ & $21(16.3 \%)$ \\
\hline
\end{tabular}

a functional pRB-p16 $6^{\mathrm{INK} 4 \mathrm{a}}$-pathway increased expression of p16 $6^{\mathrm{INK} 4 \mathrm{a}}$ and low Ki67 index can be associated with the outcome of senescence. In contrast increased $\mathrm{p} 16^{\mathrm{INK} 4 \mathrm{a}}$ expression levels associated with high Ki67 expression are often characterized by loss of pRB heterozygosity [32]. Under these conditions $\mathrm{p} 16^{\mathrm{INK} 4 \mathrm{a}}$ is an indicator for loss of $\mathrm{pRB}$ function and uncontrolled proliferation rather than a marker of senescence [31, 32]. For this reason we used $\mathrm{p} 16^{\mathrm{INK} 4 \mathrm{a}}$ expression in tumor samples with high percentages of Ki67 positive cells as an indicator of a defective $\mathrm{p} 16^{\mathrm{INK} 4 \mathrm{a}}-\mathrm{RB}$-pathway.

Given the dependence of the senescence program on the tumor suppressor pathways Arf-p53 and pRB- $\mathrm{p} 16^{\mathrm{INK} 4 \mathrm{a}}[10,1]$, we investigated whether differences in the proportion of SA $\beta$-gal-positive tumor cells within the breast cancer samples correlate with alterations in p53 and p16 $6^{\mathrm{INK} 4 \mathrm{a}}$ expression. To this end, triple negative and HER2+ breast tumor samples (low and high SA $\beta$ gal positivity, respectively (Table 3; Table 4; Figure 3)) were immunohistochemically stained for $\mathrm{p} 53$ and $\mathrm{p} 16^{\mathrm{INK} 4 \mathrm{a}}$ expression. Increased expression of p53 and p16 $6^{\mathrm{INK} 4 \mathrm{a}}$ was observed in tumor samples from both subtypes (Table 8; Figure 5), indicating alterations in these two pathways in HER2+ as well as in TNBC samples. However, alterations in both pathways in one and the same sample were only found in TNBC samples (Table 8). We observed high

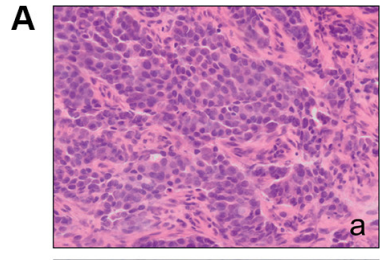

B

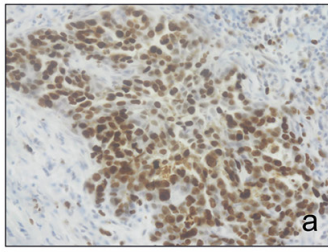

C

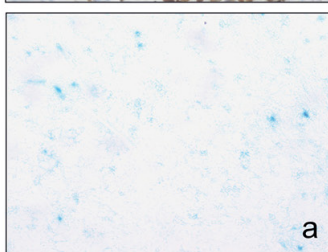

D

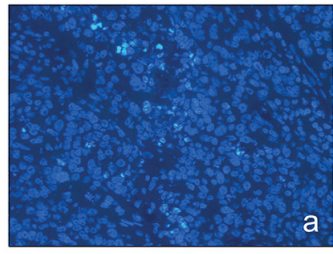

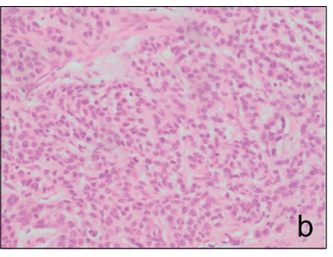
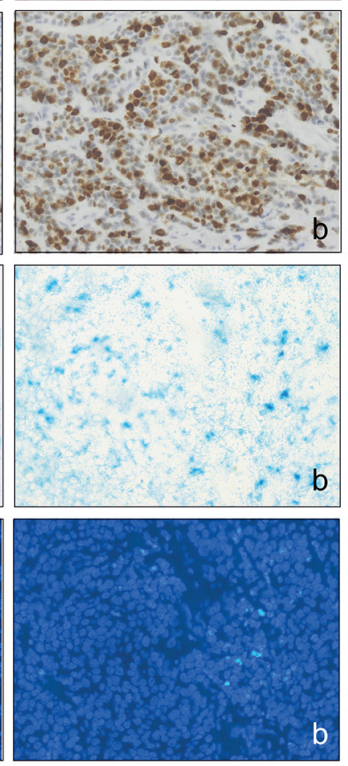
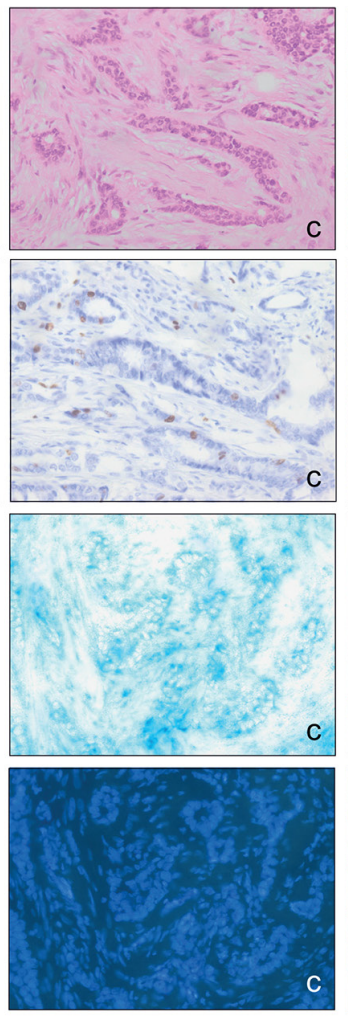

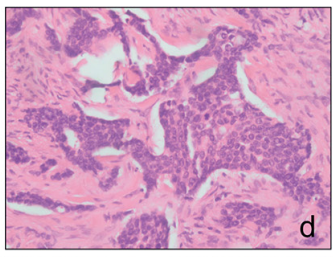

H\&E

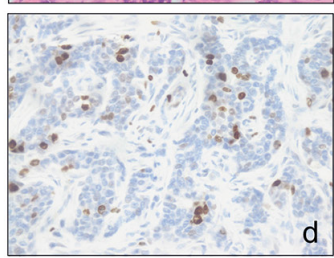

Ki67

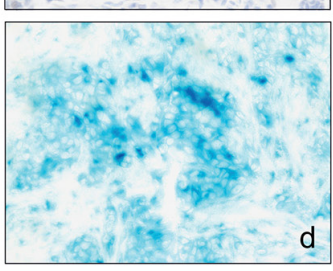

\section{d.}

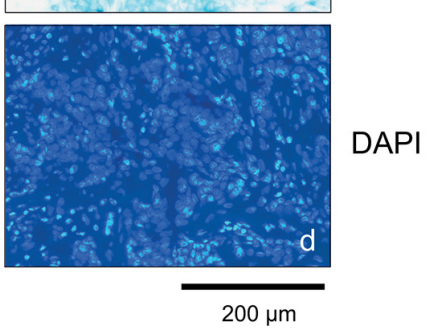

Figure 3: SA $\beta$-gal positive cells distinguish different molecular breast cancer subtypes. Tumor sections were stained with (A) (a-d) Hematoxilin and eosin, (B) (a-d) Ki67 antibodies, (C) (a-d) SA $\beta$-gal expression and (D) (a-d) DAPI. Represent examples of the different breast cancer subtypes are shown. a) TNBC; SA $\beta$-gal negative and Ki67 > 40\% b) Luminal B; SA $\beta$-gal low positive and Ki67 $>40 \%$ c) Luminal A; SA $\beta$-gal high positive and Ki67 < 40\% d) HER2 positive; SA $\beta$-gal high positive and Ki67 < $40 \%$. Bars: $200 \mu$ m. 
Table 4: Significant differences in the distribution of SA $\beta$-gal positive versus SA $\beta$-gal low + negative and $S A \beta$-gal positive versus $S A \beta$-gal negative tumor cells between breast cancer subtypes

\begin{tabular}{|c|c|c|c|c|c|c|}
\hline & SA $\beta$-gal & Cases & $\mathbf{A}$ & B & $\mathbf{C}$ & $\mathbf{D}$ \\
\hline \multirow[t]{3}{*}{ Luminal A+B } & high & 69 & $69(72.6 \%)$ & $69(72.6 \%)$ & & \\
\hline & low & 22 & \multirow{2}{*}{$26(27.4 \%)$} & & & \\
\hline & negative & 4 & & $4(4.2 \%)$ & & \\
\hline \multirow[t]{3}{*}{ Triple negative } & high & 0 & $0(0 \%)$ & $0(0 \%)$ & $0(0 \%)$ & $0(0 \%)$ \\
\hline & low & 2 & \multirow{2}{*}{$18(100 \%)$} & & \multirow{2}{*}{$18(100 \%)$} & \\
\hline & negative & 16 & & $16(88.9 \%)$ & & $16(88.9 \%)$ \\
\hline \multirow[t]{3}{*}{ HER2+ } & high & 14 & & & $14(87.5 \%)$ & $14(87.5 \%)$ \\
\hline & low & 1 & & & \multirow{2}{*}{$2(12.5 \%)$} & \\
\hline & negative & 1 & & & & $1(6.3 \%)$ \\
\hline \multicolumn{3}{|c|}{ Statistical significance } & $p<0.001$ & $p<0.001$ & $p<0.001$ & $p<0.001$ \\
\hline
\end{tabular}

expression of $\mathrm{p} 53$ within $55.5 \%$ of the TNBC samples, suggesting the presence of TP53 mutations in these cases (Table 8). In contrast, $61.1 \%$ displayed high expression of $16^{\mathrm{INK4a}}$. These findings point to loss or inhibition of $\mathrm{pRB}$ and thus impairment of the pRB-p16 $6^{\mathrm{INK} 4 \mathrm{a}}$ tumor suppressor pathway (Table 8). Interestingly, all TNBC samples with high p53 expression also exhibited high p16 $6^{\mathrm{INK} 4 \mathrm{a}}$ expression (Table 8). These observations therefore suggest that $55.5 \%$ of the TNBC samples have defects in both the Arf-p53 and the pRB-p16 ${ }^{\mathrm{INK} 4 a}$ pathways. Within the HER2+ breast cancer samples we observed high expression of p53 within $31.1 \%$ and high p16 $6^{\mathrm{INK} 4 \mathrm{a}}$ expression in $25 \%$ of the cases. However, in contrast to the TNBC samples we could not detect simultaneously high p53 and high p16 $6^{\mathrm{INK} 4 a}$ expression in the HER2+ samples (Table 8).

The cell cycle inhibitor $\mathrm{p} 21^{\text {Cip1/Wafl }}$ is a p53 target gene [33]. Elevated levels of $\mathrm{p} 21^{\text {Cip1/Wafl }}$ upon p53 activation cause cell cycle arrest and under certain conditions also senescence. Therefore increased $\mathrm{p} 21^{\mathrm{Cip} 1 /}$
Waf1 expression in association with SA $\beta$-gal expression can serve as a senescence marker, and also as a marker for p53 tumor suppressor activity in senescent cells. We therefore investigated next whether differences in the proportion of SA $\beta$-gal-positive tumor cells within the breast cancer samples correlates with $\mathrm{p} 21^{\mathrm{Cip} 1 / \text { Wafl }}$ expression. Immunohistochemical analysis of $\mathrm{p} 21^{\mathrm{Cip} / \mathrm{Wafl}}$ revealed low or even no expression of $\mathrm{p} 21^{\text {Cipl/Wafl }}$ within $77.7 \%$ of the TNBC samples (Table 8). In contrast, we observed increased expression of $\mathrm{p} 21^{\text {Cip } 1 / \text { Wafl }}$ within $68.8 \%$ of the HER2+ samples (Table 8). These findings suggest that SA $\beta$-gal positivity correlates with high $\mathrm{p} 21^{\text {Cipl/Wafl }}$ levels (Figure 3; Figure 5; Table 8), supporting the notion that SA $\beta$-gal-positive tumor cells are growth arrested and senescent. Interestingly, patient samples that showed no expression of $\mathrm{p} 21^{\text {Cip } 1 / \text { Wafl }}$ were also negative for $\mathrm{p} 53$ (Table 8). This observation suggests that loss of $\mathrm{p} 21^{\text {Cip1/ }}$ waf1 expression correlates with either inactivation of p53 protein expression or with $\mathrm{p} 53$ nonsense mutations that are not detected by the antibodies used in this study.
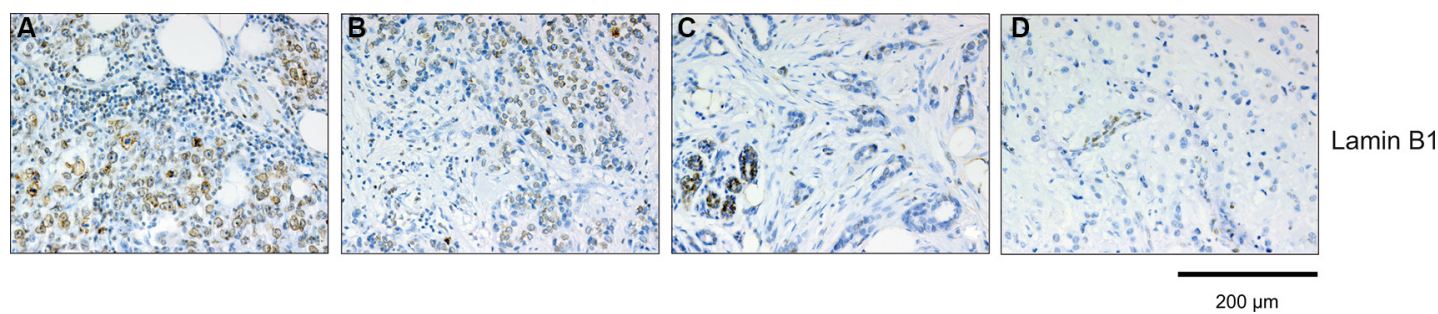

Figure 4: Immunohistochemical analysis of Lamin B1 expression within breast cancer subtypes. Tumor section were stained anti-Lamin B1 antibodies. Represent examples of the different breast cancer subtypes are shown: (A) TNBC, Lamin B1 high; (B) Luminal B, Lamin B1 high; (C) Luminal A, Lamin B1 low; (D) HER2 positive, Lamin B1 low. Luminal cells within normal ducts in sections of Luminal A and HER2 positive tumors are Lamin B1 positive and serve as internal positive control. The sections used for Lamin B1 expression are serial sections from the same tumor samples used in Figure 3. Bars: $200 \mu \mathrm{m}$. 
Table 5: Distribution of Ki67 positive cells among breast cancer subtypes

\begin{tabular}{l|c|c|c|c|c|c|c|c|}
\hline Molecular subtype & Luminal & Luminal A & Luminal B & HER2+ & $\begin{array}{c}\text { ER+/ } \\
\text { HER2+ }\end{array}$ & $\begin{array}{c}\text { ER-/ } \\
\text { HER2+ }\end{array}$ & Triple neg. & Total cases \\
\hline Number of cases & $\mathbf{9 5}$ & 77 & 18 & $\mathbf{1 6}$ & 12 & 4 & $\mathbf{1 8}$ & 129 \\
\hline$<\mathbf{4 0 \%}$ Ki67 & $\mathbf{8 9}(\mathbf{9 3 . 7 \% )}$ & $77(100 \%)$ & $12(66.7 \%)$ & $\mathbf{1 2}(\mathbf{7 5 \%})$ & $10(83.3 \%)$ & $2(50 \%)$ & $\mathbf{2 ( 1 1 . 1 \% )}$ & $103(79.8 \%)$ \\
\hline $\mathbf{4 0 \%}$ Ki67 & $\mathbf{6 ( 6 . 3 \% )}$ & $0(0 \%)$ & $6(33.3 \%)$ & $\mathbf{4 ( 2 5 \% )}$ & $2(16.7 \%)$ & $2(50 \%)$ & $\mathbf{1 6}(\mathbf{8 8 . 9} \%)$ & $26(20.1 \%)$ \\
\hline
\end{tabular}

\section{Detection of mutations within exons 5, 6, 7 and 8 of TP53 in triple negative and HER2+ breast cancer samples that express high levels of the p53 protein}

The observation that TBNC samples display no or only low numbers of SA $\beta$-gal+ tumor cells but exhibit the highest levels of p53 protein expression in IHC stainings (Figure 3; Table 3; Figure 5) suggests that TP53 mutations may lead to altered or loss of p53 function in these samples. However, although high p53 levels are suggestive of a mutated TP53 gene, not all p53 mutations result in protein accumulation. Furthermore, accumulation of wild-type p53 can also occur under certain conditions. We therefore identified TP53 mutations by genomic sequencing of TNBC and HER2+ samples with the highest p53 protein expression. In total we managed to isolate genomic DNA from eight TNBC and three HER2+ patients and performed sequencing of TP53 exons 5, 6, 7 and 8 in all of these tumor samples. Exons 5-8 encode the p53 DNA binding domain and contain $80-90 \%$ of the TP53 mutations reported in breast cancer (http://p53.iarc.fr/) [34]. The most frequent substitutions at "hotspot ${ }^{2 \text { " codons }}$ in exon 5-8 are R248Q, R248W, R175H, R273H, R273C and G245S [34]. These missense mutations lead to loss of p53 wild-type tumor suppressor activity and cause aquired oncogenic potential [34-36]. We found TP53 mutations in 6/11 patients (Table 9). Notably, two of our TNBC samples had the missense mutations R248Q and R273H (Table 9), which are associated with genomic instability, chemoresistance, reduced apoptosis, increased proliferation rates, cancer-related inflammation and
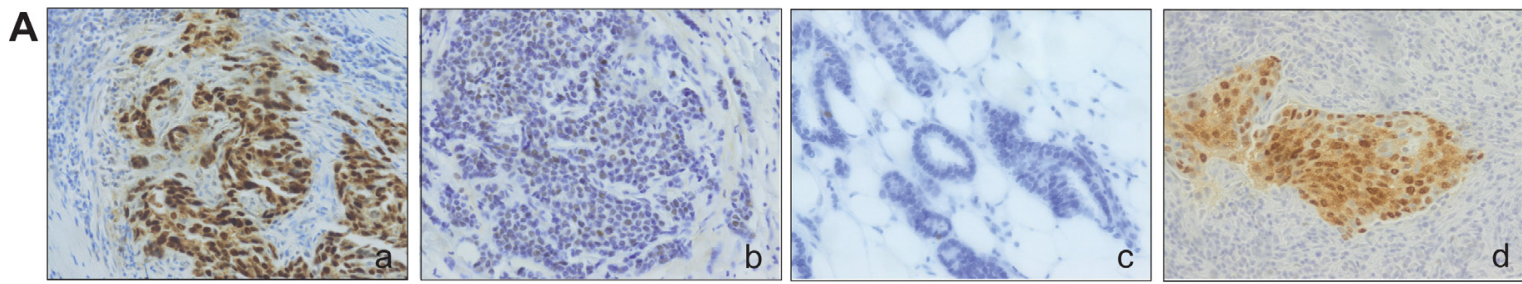

p53
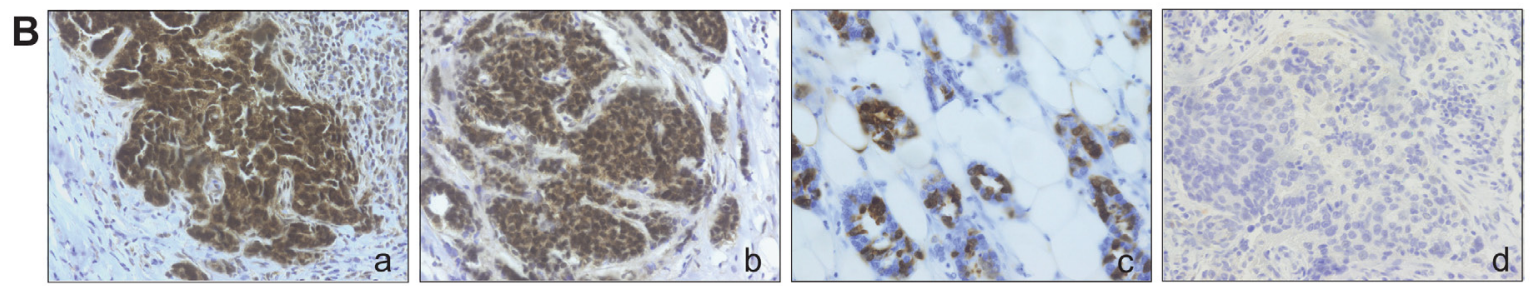

\section{d}
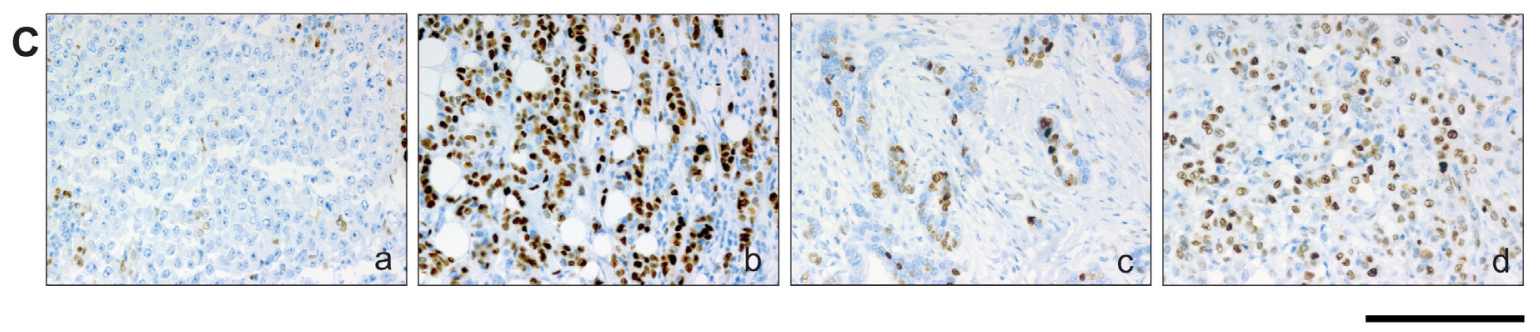

$200 \mu \mathrm{m}$

Figure 5: Immunohistochemical analysis of $\mathrm{p53}, \mathrm{p} 16^{\mathrm{INK} 4 \mathrm{a}}$ and $\mathrm{p} 21^{\mathrm{Cip1/Waf1}}$ expression within breast cancer subtypes. Tumor section were stained (A) anti-p53 antibodies and (B) anti-p16 ${ }^{\mathrm{INK} 4 \mathrm{a}}$ antibodies. Represent examples of the different breast cancer subtypes are shown: (A): (a) TNBC, p53 high; (b) Luminal B, p53 low; (c) Luminal A, p53 low; (d) HER2 positive, p53 high. (B): (a) TNBC, p16 high; (b) Luminal B, p16 high; c) Luminal A, p16 high; d) HER2 positive, p16 low. (C): (a) TNBC, p21 low; (b) Luminal B, p21 high; (c) Luminal A, p21 high; d) HER2 positive, p21 high. The sections used for p53, p16 ${ }^{\mathrm{INK} 4 \mathrm{a}}$ and p21 ${ }^{\text {Cipl/Wafl }}$ expression are serial sections from the same tumor samples used in Figure 3. Bars: $200 \mu \mathrm{m}$. 
metastasis [36]. These samples are high grade, display no numbers of SA $\beta$-gal positive cells, and contain $80-90 \%$ Ki67 positive tumor cells (Table 9). These data support the notion that TNBC samples may contain fewer senescent tumor cells due to alterations in the tumor suppressor functions of $\mathrm{p} 53$.

\section{CD68+ cells exhibit a different distribution within triple negative and HER2+ breast cancer samples}

We next investigated whether senescence in breast cancer subtypes correlates with differences in the recruitment and distribution of specific immune cells as assessed using CD68 immunostaining, a marker for monocytes and macrophages. Interestingly, we observed a different distribution of CD68+ cells within TNBC and HER2+ breast cancer samples (Figure 6A-6D). Specifically, CD68+ cells were mainly located at the stroma of HER2+ samples and were not in contact with tumor cells, whereas CD68+ cells were found between cancer cells in the majority of TNBC samples. Thus it is conceivable that the differences in the number of senescent tumor cells within different breast tumor subtypes might additionally be explained by discrepancies in the clearance of senescent tumor cells.

\section{DISCUSSION}

The notion that cellular senescence is a barrier to oncogene-induced tumorigenesis [10] is supported by studies using human and mouse tissues [4-9]. A limited number of studies have reported that senescent cells exist within premalignant human naevi and colon adenomas, but that during progression to malignant melanomas and adenocarcinomas, senescent cells disappeared or were significantly reduced in number $[4,5]$, possibly suggesting that cellular senescence may not be a feature of advanced cancers. Our study is the first to date to investigate this issue, and we clearly show that in the context of untreated invasive human breast tumors, significant numbers of senescent cells can be present, in a manner that is dependent on the breast cancer subtype. Specifically we found that high percentages of SA $\beta$-gal positive cancer cells exist within luminal A and HER2+ amplified breast tumors, while few if any SA $\beta$-gal positive cancer cells were observed in TNBC samples. The inverse correlation between SA $\beta$-gal positive and Ki67 positive cancer cells (Table 6) suggests that SA $\beta$-gal positive cancer cells do not proliferate. Loss or decreased amounts of Lamin B1 within the nuclear membrane also correlated with high SA $\beta$-gal positivity, supporting the notion that SA $\beta$-gal positive cells are indeed in the state of senescence [26-28]. As we only included samples in our study from patients who had not received neoadjuvant treatment, we can exclude the possibility that the appearance of senescent tumor cells was the consequence of previous anti-cancer regimens. Therefore, the presence of SA $\beta$-gal positive tumor cells must be caused by either a mechanism intrinsic to the tumor cells themselves or by the microenvironment around them.

The most likely tumor-cell intrinsic mechanism that may underlie the differences in senescene we observed amongst different subtypes of breast cancer are subtypespecific oncogenic stimuli that lead to the initiation and progression of breast cancer. We note that different breast cancer subtypes are typified by distinct subsets of genetic and epigenetic abnormalities [38]. Given the role of senescence as a barrier to oncogene-induced transformation, one explanation of our findings could be that breast cancer subtypes vary in their ability to senesce due to underlying differences in driver mutations and other genetic defects. Another possibility might be that breast cancer subtypes differ in their ability to recruit immune cells that eliminate senescent cells.

The ability of cells to induce the senescence program upon oncogenic stimuli depends mainly on the tumor suppressor pathways Arf-p53 and pRB-p16 $6^{\mathrm{INK} 4 \mathrm{a}}$ $[10,1]$. Defects in either one or both of these pathways can circumvent the ability of cells to undergo senescence and increases the susceptibility to cancer progression [6, 11-13, 31, 32]. Although TP53 mutations are common in human breast cancers and occur in approximately $37 \%$ of all cases, there are clear differences between different breast cancer subtypes. Basal-like TNBCs have TP53 mutations in around $80 \%$ of all cases [38]. The majority
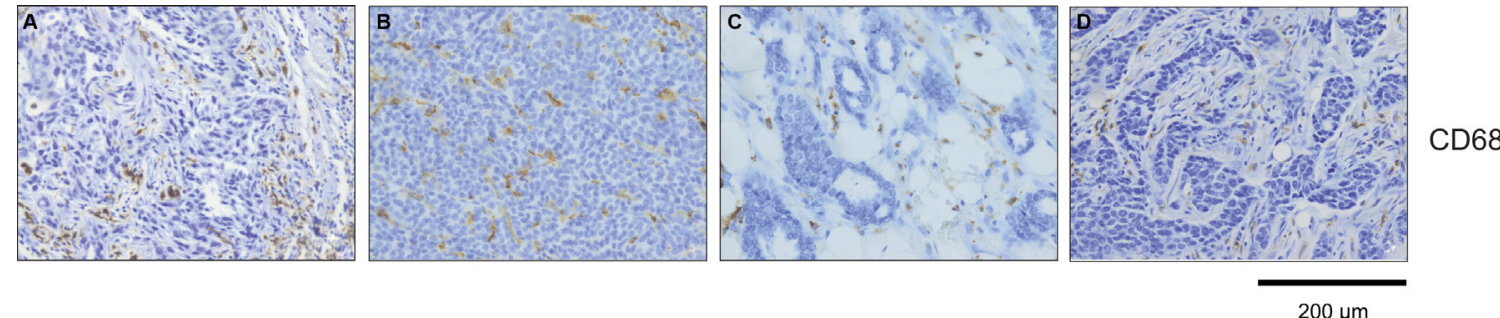

Figure 6: CD68 positive cells are differentially distributed between tumor and stroma within breast cancer subtypes. Detection of CD68 positive cells within tumor samples (A) TNBC, CD68+ cells within tumor; (B) Luminal B, CD68+ cells within tumor; (C) Luminal A, CD68+ cells within tumor stroma; (D) HER2 positive, CD68+ cells within tumor stroma. Bars: $200 \mu \mathrm{m}$. 
Table 6: Significant inverse correlation between SA $\beta$-gal positivity and Ki67 expression

\begin{tabular}{|c|c|c|c|c|c|}
\hline & SA $\beta$-gal & Cases & $\mathbf{A}$ & B & $\mathbf{C}$ \\
\hline \multirow[t]{3}{*}{$<40 \%$ Ki67 } & high & 76 & $76(73.8 \%)$ & $76(73.8 \%)$ & $76(73.8 \%)$ \\
\hline & low & 24 & \multirow{2}{*}{$27(26.2 \%)$} & & $24(23.3 \%)$ \\
\hline & negative & 3 & & $3(2.9 \%)$ & \\
\hline \multirow[t]{3}{*}{$\geq 40 \%$ Ki67 } & high & 7 & $7(26.9 \%)$ & $7(26.9 \%)$ & $7(26.9 \%)$ \\
\hline & low & 4 & \multirow{2}{*}{$19(73.1 \%)$} & & $4(15.4 \%)$ \\
\hline & negative & 15 & & $15(57.9 \%)$ & \\
\hline \multicolumn{3}{|c|}{ Statistical significance } & $p<0.001$ & $p<0.001$ & $p=0.4$ \\
\hline
\end{tabular}

Table 7: Lamin B1 expression within triple negative and HER2+ breast cancer

\begin{tabular}{|l|c|c|l|c|c|}
\hline \multicolumn{1}{c}{ Molecular subtype } & \multicolumn{1}{c}{ Cases } & $\mathbf{\%}$ & \multicolumn{1}{c}{ Molecular subtype } & Cases & $\mathbf{1 0}$ \\
\hline HER2+ & $\mathbf{1 6}$ & $\mathbf{1 0 0}$ & Triple negative & $\mathbf{1 8}$ & $\mathbf{1 0 0}$ \\
\hline LaminB1 high & 3 & 18.8 & LaminB1 high & 15 & 83.3 \\
\hline LaminB1 low & 3 & 18.8 & LaminB1 low & 0 & 0 \\
\hline LaminB1 negative & 10 & 62.5 & LaminB1 negative & 3 & 16.7 \\
\hline
\end{tabular}

of TP53 mutations in TNBCs are nonsense and frame shift mutations leading either to complete loss of p53 tumor suppressor function or gain of oncogenic features. Thus, loss of p53 tumor suppressor function through mutation within TNBCs might be one possible explanation why senescent cancer cells were so few or even absent from the TNBCs in our study. Consistent with this notion, we observed high expression of p53 in $55.5 \%$ of our TNBC samples (Table 8 ) and found mutations in exons 5-8 of TP53 in 5/8 TNBC samples with the highest p53 protein levels (Table 9). Moreover, $61.1 \%$ of the TNBCs displayed high expression of $\mathrm{p} 16^{\mathrm{INK} 4 \mathrm{a}}$ associated with high percentages of Ki67 positive cells (Table 8), indicating impairment of the pRB-p $16^{\mathrm{INK} 4 \mathrm{a}}$ tumor suppressor pathway $[31,32]$. Interestingly, all TNBC samples with high p53 expression also displayed high $\mathrm{p} 16^{\mathrm{INK} 4 \mathrm{a}}$ expression and $88.9 \%$ were either low or negative for $\mathrm{p} 21^{\text {Cip } 1 / \text { Wafl }}$ expression (Table 8). Thus it is likely that over half of the TNBC samples had defects in both Arf-p53 and pRBp16 $6^{\mathrm{INK} 4 \mathrm{a}}$, providing a further possible reason for why so few senescent cells were detected in the TNBC samples.

Almost all TNBC samples with high p53 protein levels exhibited low numbers of $\mathrm{p} 21^{\text {Cip } 1 / \text { Wafl }}$ positive cells, possibly indicating alterations in p53 tumor suppressor activity (Table 9). Interestingly, only the TNBC patient sample with the missense mutation R248Q showed increased expression of $\mathrm{p} 21^{\text {Cip/Nafl }}$ (Table 9). This observation might point to a p53-independent mechanism that causes $\mathrm{p} 21^{\text {Cip } 1 / \text { Wafl }}$ overexpression within this tumor sample. Furthermore, it was recently reported that subsets of p53-deficient human cancer cells and tumors exhibit chronic overexpression of nuclear $\mathrm{p} 21^{\text {Cip1/Wafl }}$, which in turn leads to escape from senescence, deregulation of replication licensing, replication stress, genomic instability and chemotherapy resistance [37]. Thus, $\mathrm{p} 21^{\text {Cip } 1 / \text { Wafl may }}$ exert tumor-promoting effects in the context of certain p53 mutations.

Luminal A breast tumors in general have the best prognosis and are those tumors most likely to retain activity of the major tumour suppressor pathways Arf-p53 and pRB-p16 $6^{\mathrm{INK} 4 \mathrm{a}}$ [38]. TP53 mutations within luminal $\mathrm{A}$ and $\mathrm{B}$ breast cancers are predominantly missense mutations and do not always inevitably cause complete reduction of $\mathrm{p} 53$ tumor suppressor function. They also occur at a much lower frequency than in TNBC, with approximately $12 \%$ of luminal A and $29 \%$ of luminal B tumors having TP53 mutations [38]. It is therefore interesting to note that $75.3 \%$ of the luminal A samples contained SA $\beta$-gal positive cancer cells, in contrast to $61.1 \%$ in the luminal B samples (Table 3). Thus the reduced number and type of TP53 mutations within luminal A breast tumors in particular is likely to contribute to the larger numbers of senescent cells in this breast cancer subtype.

A large proportion $(87.5 \%)$ of the HER $2+$ breast cancer samples in this study contained SA $\beta$-gal-positive cancer cells. At the same time we observed high expression of $\mathrm{p} 53$ within $31.1 \%$ of the samples (probably indicative of TP53 mutations in these cases), high $\mathrm{p} 16^{\mathrm{INK} 4 \mathrm{a}}$ expression in $25 \%$ and high p $21^{\text {Cip } 1 / \text { Wafl }}$ expression in $68.8 \%$ of the samples (Table 8). In the HER2+ breast cancer sample in which we found a p53 mutation within codon 272 of exon 
Table 8: Different p53, p16 ${ }^{\text {INK4a }}$ and p21 ${ }^{\text {Cip1/Waf1 }}$ expression in triple negative and HER2+ breast cancer samples

\begin{tabular}{l|c|c|l|c|c|}
\multicolumn{1}{c}{ Molecular subtype } & \multicolumn{1}{c}{ Cases } & Molecular subtype & Cases & \% \\
\hline HER2+ & $\mathbf{1 6}$ & $\mathbf{1 0 0}$ & Triple negative & $\mathbf{1 8}$ & $\mathbf{1 0 0}$ \\
\hline p53 high & 5 & 31.3 & p53 high & 10 & 55.5 \\
\hline p53 low & 8 & 50 & p53 low & 5 & 27.7 \\
\hline p53 negative & 3 & 18.8 & p53 negative & 3 & 16.7 \\
\hline p16 high & 4 & 25 & p16 high & 11 & 61.1 \\
\hline p16 low & 8 & 50 & p16 low & 3 & 16.7 \\
\hline p16 negative & 4 & 25 & p16 negative & 4 & 22.2 \\
\hline p53 high + p16 high & $\mathbf{0}$ & $\mathbf{0}$ & p53 high + p16 high & $\mathbf{1 0}$ & $\mathbf{5 5 . 5}$ \\
\hline p21 high & 11 & 68.8 & p21 high & 2 & 11.1 \\
\hline p21 low & 3 & 18.8 & p21 low & 14 & 77.7 \\
\hline p21 negative & 2 & 12.5 & p21 negative & 2 & 11.1 \\
\hline p53 neg. + p21 neg. & $\mathbf{2}$ & $\mathbf{1 2 . 5}$ & p53 neg. + p21 neg. & $\mathbf{2}$ & $\mathbf{1 1 . 1}$ \\
\hline
\end{tabular}

8, a high percentage of SA $\beta$-gal positive tumor cells was observed (Table 9), indicating that either the p53 mutation has no consequences, or that HER2+ tumor cells still have the ability to senesce even if p53 is mutated. Collectively these observations suggest that HER2+ tumor cells can senesce even in the presence of a defective Arf-p53 or $\mathrm{p} 16^{\mathrm{INK} 4 \mathrm{a}}$ pathway in at least some of the samples. A possible explanation might be that even if HER2+ breast cancer cells harbour $\mathrm{p} 53$ or $\mathrm{p} 16^{\mathrm{INK} 4 \mathrm{a}}$ mutations, they may still be susceptible to induction of senescence. Alternatively or in addition, it has been reported that the secretome of senscent cells transformed by constitutive HER2 signalling inhibits the clearance of senescent cells and exerts prometastatic effects [25]. Thus, the high percentage of SA $\beta$-gal positive cancer cells within our HER2+ breast cancer samples might suggest that oncogenic HER2-induced senescence results in a secretome that can inhibit the recruitment of immune cells and thereby reduced elimination of the senescent cells, leading to accumulation of senescent cells within these tumors. It is also conceivable that the secretome might increase the ability of non-senescent cancer cells to proliferate and metastasize.

The secretome produced by senescent cells can trigger senescence surveillance within liver tumors through the recruitment of macrophages, neutrophils and NK cells $[16,19]$. It is therefore of note that immunohistochemical staining for the monocyte/ macrophage marker CD68 revealed a breast cancer subtype-specific distribution of macrophages within the 129 breast cancer samples used in this study. In the HER2+ samples, macrophages were mainly located at the stroma and not in contact with tumor cells, while in the majority of TNBC samples, macrophages could be found between cancer cells (Figure 6). This observation suggests that breast tumors subtypes may differ in their SASP and thus in their ability to recruit immune cells to clear senescent cells $[16,18,19,25]$.

The secreome produced by senescent cells can affect the behavior of neighboring cells [1], and may contribute to the ability of senescent cells to promote malignant progression in mice xenograft models [24, 22]. Furthermore, the secretome of senscent cells transformed by constitutive HER2 signalling inhibits the clearance of senescent cells, leading to pro-metastatic effects that can contribute to breast cancer progression [25]. Therefore, it is conceivable that senescent cells within human cancers might contribute to disease progression. Notably, some subpopulations of immune cells can inhibit tumor growth, whereas others promote tumor progression and metastasis [39]. The secretome of senescent cells contains chemokines and other factors that can recruit specific types of immune cell. Thus the exact constituents of the secretome produced by senescent tumor cells may determine whether senescence serves to restrict tumor growth or rather promotes it through the recruitment of tumor-promoting immune cells.

In summary, our observations indicate that senescent tumor cells exist within advanced human breast cancers, and that the proportion of senescent tumor cells varies strongly according to the breast cancer subtype. High percentages of SA $\beta$-gal positive tumor cells exist within luminal A and HER2+ breast cancer samples, whereas no or very few SA $\beta$-gal positive tumor cells are found within TNBCs. One possible explanation for these observations might be that these tumors differ in their genetic and epigenetic alterations, and therefore vary in their capacity to senesce. In addition, clearance of senescent tumor cells may depend on the underlying 
Table 9: Mutations within exons 5, 6, 7 and 8 of TP53 in triple negative and HER2+ breast cancer samples that express high levels of the $\mathrm{p53}$ protein

\begin{tabular}{|c|c|c|c|c|c|c|c|c|c|c|c|c|}
\hline $\begin{array}{l}\text { Patient } \\
\text { sample }\end{array}$ & $\begin{array}{l}\text { Molecular } \\
\text { subtype }\end{array}$ & Histology & Grading & SA $\beta$-gal & Ki67 & p53 & p21 ${ }^{\text {Cip1/Waf1 }}$ & p16 $6^{\text {Ink4A }}$ & Exon & \multicolumn{3}{|c|}{$\begin{array}{l}\text { Codon } \\
\text { Mutation }\end{array}$} \\
\hline 1. & TNBC & invasive ductal & G3 & negative & $80 \%$ & high & low & high & 6 & \multicolumn{3}{|c|}{$\begin{array}{c}\mathrm{P} 223 \mathrm{~L} \\
\mathrm{C} \underline{\boldsymbol{C}} \mathrm{T} \rightarrow \mathrm{CTT}\end{array}$} \\
\hline 2. & TNBC & invasive ductal & G3 & negative & $80 \%$ & high & low & high & 8 & \multicolumn{3}{|c|}{$\begin{array}{c}\mathrm{R} 273 \mathrm{H} \\
\mathrm{CG} \rightarrow \mathrm{CAT}\end{array}$} \\
\hline 3. & TNBC & invasive ductal & G2 & negative & $40 \%$ & high & low & high & - & \multicolumn{3}{|c|}{ - } \\
\hline 4. & TNBC & invasive ductal & G3 & negative & $70 \%$ & high & low & high & - & \multicolumn{3}{|c|}{-} \\
\hline 5. & TNBC & invasive ductal & G3 & negative & $90 \%$ & high & high & high & 7 & \multicolumn{3}{|c|}{$\begin{array}{c}\mathrm{R} 248 \mathrm{Q} \\
\mathrm{C} \underline{\mathbf{G G}} \rightarrow \mathrm{CAG}\end{array}$} \\
\hline 6. & TNBC & invasive ductal & G3 & negative & $80 \%$ & high & low & negative & 5 & $\begin{array}{l}\mathrm{N} 131 \mathrm{~K} \\
\mathrm{AAC} \rightarrow \mathrm{AAG}\end{array}$ & $\begin{array}{c}\mathrm{K} 132 \mathrm{M} \\
\mathrm{A} \underline{\boldsymbol{A}} \mathrm{G} \rightarrow \mathrm{ATG}\end{array}$ & $\begin{array}{l}\text { M133del } \\
\text { ATG } \rightarrow \text { G }\end{array}$ \\
\hline 7. & TNBC & invasive ductal & G3 & negative & $20 \%$ & high & low & low & - & \multicolumn{3}{|c|}{-} \\
\hline 8. & TNBC & invasive ductal & G3 & negative & $90 \%$ & high & low & low & 5 & \multicolumn{3}{|c|}{$\begin{array}{c}\mathrm{C} 176 \mathrm{Y} \\
\mathrm{T} \underline{G} \mathrm{C} \rightarrow \mathrm{TAC}\end{array}$} \\
\hline 9. & HER2+ & invasive ductal & G3 & negative & $60 \%$ & high & low & low & - & \multicolumn{3}{|c|}{-} \\
\hline 10. & HER2+ & invasive ductal & G3 & high & $40 \%$ & high & high & low & 8 & \multicolumn{3}{|c|}{$\begin{array}{c}\mathrm{V} 272 \mathrm{~L} \\
\underline{\boldsymbol{G}} \mathrm{TG} \rightarrow \mathbf{T T G}\end{array}$} \\
\hline 11. & HER2+ & invasive ductal & G3 & high & $20 \%$ & high & high & negative & - & \multicolumn{3}{|c|}{-} \\
\hline
\end{tabular}

oncogenes that induce senescence, probably because of differences in their SASP [22, 24, 15, 17]. We suggest that the composition of secretory phenotypes released by senescent tumor cells from different breast cancer subtypes might be very distinct in respect to their ability to recruit immune cells, which can eliminate senescent cells on one hand and regulate tumor growth on the other. Further characterization of the SASPs from different breast cancers subtypes and their potential role in tumor progression is therefore warranted.

\section{MATERIALS AND METHODS}

\section{Patient samples}

Tumor tissue from 176 patients with primary early breast cancer was collected between January 2011 and December 2013 in the Institute of Pathology, Johannes Gutenberg University, Mainz (66 patients in 2011; 78 patients in 2012 and 32 patients in 2013). All patients received a modified radical mastectomy or breastconserving therapy with sentinel lymph node resection or axillary lymph node dissection. Patients who had been given neoadjuvant therapy were excluded from this study. All included patients had pathological evaluation carried out at the Institute of Pathology. The clinicopathologic data collected included patient age, histological tumour type, TNM classification, histological grade, oestrogen receptor status (ER), progesterone receptor status (PR), HER-2-neu status (HER2) and proliferation index (Ki67). The original pathology reports from all included patients were used. Tumors were staged according to the TNM classification of malignant Tumours (7th Edition 2009), and were classified according to the WHO classification of tumours of the breast [40]. Histological grade was scored according to the Nottingham histologic score system (the Elston-Ellis modification of the Scarff-Bloom-Richardson grading system) [41].

The frozen human breast tumour tissue used in this study was collected immediately after an intraoperative diagnostic evaluation. All cases were previously histologically diagnosed with a preoperative needle core biopsy. The intraoperative assessment served only as delimitation and evaluation of the microscopic tumor margins. For this evaluation the margins of the surgical specimen were marked with ink. Tumor with the nearest surgical margin was frozen (Figure 1A). In Figure 1 the nearest surgical margin was marked with orange ink. One frozen section was obtained, stained with eosin and hematoxylin (H\&E) using standard laboratory procedures, and intraoperatively examined (Figure 1B). A second cryosection of the frozen breast tissue from each case was obtained and collected for further analysis (Figure 1C). In only 129 of the 176 cases did the frozen sections contain enough invasive tumor tissue to be included in this study. Two patients had a non-invasive breast cancer. In 12 cases only non-invasive tumour was detected in the cryosection and in 33 cases there was not enough tumor tissue in the cryosection.

\section{Ethics statement}

The use of the patient tissue samples have been conducted in accordance with the ethical standards and 
according to the Declaration of Helsinki and according to national and international guidelines and have been approved by the authors' local ethical review board.

\section{Immunohistochemical detection and scoring method}

Formalin-fixed, paraffin-embedded tumor sections were used for immunhistochemical detection. Immunohistochemistry was performed using standard laboratory procedures. Staining was performed on an immunostainer (Techmate 500; Dako, Glostrup, Denkmark) according to the manufacturer's instructions. The antigen-antibody binding was visualised by means of the avidin-biotin complex (ABC method) using AEC (3-amino-9ethylcarbazol) as chromogen. The primary monoclonal antibodies used in this study were purchased from Dako (Glostrup, Denmark) and were directed agains ER (1D5), PR (1A6), Ki67 antigen (MIB-5), p21 $1^{\text {Cip1/Waf1 }}$ (Sx1118) and p53 (DO-7) or Abcam (Cambridge, UK) directed against Lamin B1 (ab16048). The p16 ${ }^{\mathrm{INK} 4 \mathrm{~A}}$ expression was analysed using CINtec ${ }^{\mathrm{TM}}$ p16 (E6H4) (Roche Diagnostics, Basel, Switzerland). The HER2 status was determined by using the Hercept-test and HER2 FISH pharmDx ${ }^{\mathrm{TM}}$ Assay Kit (Dako, Glostrup, Denmark).

Ki67 proliferative index, p16 $6^{\mathrm{INK} 4 \mathrm{a}}, \mathrm{p} 21^{\mathrm{Cip} 1 / \text { Waf1 }}$, p53 and Lamin B1 protein expression were quantified on the basis of percentage positivity in at least 500 neoplastic cells counted in the tumor area. For Ki67 proliferative index, p16 ${ }^{\mathrm{INK} 4 \mathrm{a}}, \mathrm{p} 21^{\mathrm{Cip} 1 / \mathrm{Wafl}}$ and $\mathrm{p} 53$ expression only nuclear reactivity and for Lamin B1 only reactivity of the nuclear membrane was taken into account. ER and PR status were determined on the basis of the immunohistochemical intensity and the percentage of positive cells. A strong nuclear staining in one or more tumor cells was considered positive. Complete and strong membrane staining in $>10 \%$ of the tumour cells qualified for HER2 overexpression (3+). A HER2:Cep17 ratio > 2.0 was regarded as a HER2 amplified tumor [42].

\section{St. Gallen risk groups}

We classified all cases in accordance with the St. Gallen international breast cancer conference guidelines from 2013 with the suggested definition of intrinsic subtypes of breast cancer: luminal-A (ER+ and PR+, Ki67 low $(\leq 20 \%)$ and HER2-), luminal-B (ER+ and PR-/low, or Ki67 high ( $>20 \%$ ) and HER2+/-), HER-2 positive $(\mathrm{ER}-, \mathrm{PR}-$ and HER2+) and triple negative (ER-, PR-, HER2-) [43].

\section{Senescence-associated $\beta$-galactosidase activity}

Senescence-associated $\beta$-galactosidase (SA $\beta$-gal) activity at $\mathrm{pH} 6.0$, the standard biomarker of cellular senescence, was detected in vitro or in vivo as described previously [44]. Briefly, frozen sections of human breast tumors were dried over night at room temperature and subsequently fixed with $2 \%$ formaldehyde and $0.2 \%$ glutaraldehyde for 1 hour at room temperature. After fixation, the sections were incubated in $\beta$-galactosidase staining solution [44] for 24 hours at $37 \mathrm{C}^{\circ}$. Betagalactosidase was purchased from Carl Roth $\mathrm{GmbH}$, Karlsruhe, Germany. For visualization of the nuclei, sections were incubated in 4',6-Diamidino-2-phenylindole (DAPI, Sigma Adrich, Taufkirchen Germany).

\section{Sequencing of genomic DNA from formalin-fixed and paraffin-embedded tumor samples}

Tumor areas of serial sections were selectively scratched off according to corresponding HE-slides and, following de-paraffination and Proteinase-K digestion, used for DNA preparation. PCR amplfication was carried out using the primers listed in supplemental information and afterwards the PCR products were ExoSAP (Affymetrix, Santa Clara, California, USA) digested and sequenced directly using the same primers. At least 2 independent PCR products of each exon 5-8 from each patient were sequenced in two different orientations.

\section{Statistical analysis}

All data were analysed in Microsoft Excel. A Fisher's exact test was performed. A $p$-value of $<0.001$ was considered to be statistically significant.

\section{ACKNOWLEDGMENTS}

The authors are grateful to the technicans in the Institute of Pathology in Mainz for excellent technical assistance.

\section{CONFLICTS OF INTEREST}

The authors have no conflicts of interest to disclose.

\section{GRANT SUPPORT}

Financial support was obtained from the Deutsche Forschungsgemeinschaft (DFG grant TH1523/1-2 and TH1523/2-2 to S. Thaler).

\section{Authors' contributions}

ST designed research, performed SA $\beta$-gal stainings. CLC organized tissue sample collection and performed histopathological analysis, CLC, ST and AS analyzed SA $\beta$-gal stained tissue sections. ES performed TP53 sequencing. ST and ES analysed sequencing results. ST and CLS designed figures and tables. ST, CLS and JPS 
drafted and edited the paper. MS provided clincal data and critically read the manuscript. JCK critically read the manuscript and gave helpful advice. All authors read and approved the manuscript.

\section{REFERENCES}

1. Rodier F, Campisi J. Four faces of senescence. J Cell Biol. 2011; 192:547-56.

2. Shay JW, Roninson IB. Hallmarks of senescence in carcinogenesis and cancer therapy. Oncogene. 2004; 23:2919-33.

3. Hanahan D, Weinberg RA. The hallmarks of cancer. Cell. 2000; 100:57-70.

4. Bartkova J, Horejsi Z, Koed K, Krämer A, Tort F, Ziegler K, Guldberg P, Sehested M, Nesland JM, Lukas C, Orntoft T, Lukas J, Bartek J. DNA damage response as a candidate anti-cancer barrier in early human tumorigenesis. Nature. 2005; 434:864-870.

5. Michaloglou C, Vredeveld LC, Soengas MS, Denoyelle C, Kuilman T, van der Horst CM, Majoor DM, Shay JW, Mooi WJ, Peeper DS. BRAFE600-associated senescencelike cell cycle arrest of human naevi. Nature. 2005; 436:720-724.

6. Chen Z, Trotman LC, Shaffer D, Lin HK, Dotan ZA, Niki M, Koutcher JA, Scher HI, Ludwig T, Gerald W, Cordon-Cardo C, Pandolfi PP. Crucial role of p53dependent cellular senescence in suppression of Ptendeficient tumorigenesis. Nature. 2005; 436:725-30.

7. Collado M, Gil J, Efeyan A, Guerra C, Schuhmacher AJ, Barradas M, Benguria A, Zaballos A, Flores JM, Barbacid M, Beach D, Serrano M. Tumour biology: senescence in premalignant tumors. Nature. 2005; 436:642.

8. Braig M, Lee S, Loddenkemper C, Rudolph C, Peters AH, Schlegelberger B, Stein H, Dörken B, Jenuwein T, Schmitt CA. Oncogene-induced senescence as an initial barrier in lymphoma development. Nature. 2005; 436:660-665.

9. Collado M, Serrrano M. Senescence in tumors: evidence from mice and humans. Nat Rev Cancer. 2010; 10:51-7.

10. Serrano M, Lin AW, McCurrach ME, Beach D, Lowe SW. Oncogenic ras provokes premature cell senescence associated with accumulation of p53 and p16INK4a. Cell. 1997; 88:593-602.

11. Beausejour CM, Krtolica A, Galimi F, Narita M, Lowe SW, Yaswen P, Campisi J. Reversal of human cellular senescence: roles of the p53 and p16 pathways. EMBO J. $2003 ; 22: 4212-4222$.

12. Brenner AJ, Stampfer MR, Aldaz CM. Increased p16 expression with first senescence arrest in in human mammary epithelial cells and extended growth capacity with p16 inactivation. Oncogene. 1998; 17:199-205.

13. Schmitt CA, Friedman JS, Yang M, Lee S, Baranow E, Hoffman RM, Lowe SW. A senescence program controlled by $\mathrm{p} 53$ and $\mathrm{p} 16 \mathrm{INK} 4 \mathrm{a}$ contributes to the outcome of cancer therapy. Cell. 2002; 109:335-46.

14. te Poele RH, Okorokov AL, Jardine L, Cummings J, Joel SP. DNA damage is able to induce senescence in tumor cells in vitro and in vivo. Cancer Res. 2002; 62:1876-83.

15. Ventura A, Kirsch DG, McLaughlin ME, Tuveson DA, Grimm J, Lintault L, Newman J, Reczek EE, Weissleder R, Jacks T. Restoration of p53 function leads to tumor regression in vivo. Nature. 2007; 445:661-665.

16. Xue W, Zender L, Miething C, Dickins RA, Hernando E, Krizhanovsky V, Cordon-Cardo C, Lowe SW. Senescence and tumour clearance is triggered by p53 restoration in murine liver carcinomas. Nature. 2007; 445:656-660.

17. Lin HK, Chen Z, Wang G, Nardella C, Lee SW, Chan CH, Yang WL, Wang J, Egia A, Nakayama KI, Cordon-Cardo C, Teruya-Feldstein J, Pandolfi PP. Skp2 targeting suppresses tumorigenesis by Arf-p53-independent cellular senescence. Nature. 2010; 464:374-9.

18. Kang TW, Yevsa T, Woller N, Hoenicke L, Wuestefeld T, Dauch D, Hohmeyer A, Gereke M, Rudalska R, Potapova A, Iken M, Vucur M, Weiss S, et al. Senescence surveillance of pre-malignant hepatocytes limits liver cancer development. Nature. 2011; 479:547-551.

19. Hoenicke L, Zender L. Immune surveillance of senescent cells - biological significance in cancer and non-cancer pathologies. Carcinogenesis. 2012; 33:1123-1126.

20. Kuilman T, Peeper DS. Senescence-messaging secretoms: SMS-ing cellular stress. Nat Rev Cancer. 2009; 9:81-94.

21. Bavik C, Coleman I, Dean JP, Knudsen B, Plymate S, Nelson PS. The gene expression program of prostate fibroblast senescence modulates neoplastic epithelial cell proliferation through paracrine mechanisms. Cancer Res. 2006; 66:794-802.

22. Coppe JP, Desprez PY, Krtolica A, Capisi J. The senescenceassociated secretory phenotype: the dark side of tumor suppression. Annu Rev Pathol. 2010; 5:99-118.

23. Coppe JP, Patil CK, Rodier F, Sun Y, Munoz DP, Goldstein J, Nelson PS, Desprez PY, Campisi J. Senescence-associated secretory phenotypes reveal cell-nonautonomous functions of oncogenic RAS and the p53 tumor suppressor. PLOS Biol. 2008; 6:2853-2868.

24. Krtolica A, Perrinello S, Lockett S, Desprez PY, Campisi J. Senescent fibroblasts promote epithelial cell growth and tumorigenesis: a link between cancer and aging. Proc. Natl. Acad. Sci. USA. 2001; 98:12072-12077.

25. Angelini PD, Zacharias Fluck MF, Pedersen K, ParraPalau JL, Guiu M, Bernado Morales C, Vicario R, LuqueGarcia A, Navalpotro NP, Giralt J, Canals F, Gomis RR, Tabernero J, et al. Constitutive Her2 signaling promotes breast cancer metastasis through cellular senescence. Cancer Res. 2013; 73:450-458.

26. Freund A, Laberge RM, Demira M, Campisi J. Lamin B1 loss is a senescence-associated biomarker. Mol Biol Cell. 2012; 23:2066-2075. 
27. Shimi T, Butin-Israeli V, Adam SA, Hamanaka RB, Goldman AE, Lucas CA, Shumaker DK, Kosak ST, Chandel NS, Goldman RD. The role of nuclear lamin B1 in cell proliferation and senescence. Genes Dev. 2011; 15:2579-2593.

28. Shah PP, Donahue G, Otte GL, Capell BC, Nelson DM, Cao K, Aggarwala V, Cruickshanks HA, Rai TS, McBryan T, Gregory BD, Adams PD, Berger SL. Lamin B1 depletion in senescent cells triggers large-scale changes in gene expression and the chromatin landscape. Genes Dev. 2013; 27:1787-1799.

29. Milde-Langosch K, Bamberger AM, Rieck G, Kelp B, Löning T. Overexpression of p16 cell cycle inhibitor in breast cancer is associated with a more malignant phenotype. Breast Cancer Res Treat. 2001; 67:61-70.

30. Zhang J, Pickering CR, Holst CR, Gauthier ML, Tlsty TD. p16INK4a modulates p53 in primary human mammary epithelial cells. Cancer Res. 2006; 66:10325-10331.

31. Herschkowitz JI, HE X, Fan C, Perou CM. The functional loss of the retinoblastoma tumour suppressor is a common event in basal-like and luminal B breast carcinomas. Breast Cancer Res. 10: R75.

32. Romagosa C, Simonetti S, Lopez-Vincente L, Mazo A, Lleonart ME, Castellvi J, Ramon y Cajal S. p16 $6^{\text {Ink4a }}$ overexpression in cancer: a tumor suppressor gene associated with senescence and high-grade tumors. Oncogene. 2011; 30:2087-2097.

33. El-Deiry WS, Tokino $\mathrm{T}$, Velculescu VE, Levy DB, Parsons R, Trent JM, Lin D, Mercer WE, Kinzler KW, Vogelstein B. WAF1, a potential mediator of p53 tumor suppression. Cell. 1993; 75:817-825.

34. Olivier M, Langerod A, Carrieri P, Bergh J, Klaar S, Eyfjord J, Theillet C, Rodriguez C, Lidereau R, Bieche I, Varley J, Bignon Y, Uhrhammer N, et al. The clinical value of somatic TP53 gene mutations in 1,794 patients with breast cancer. Clin Cancer Res. 2006; 12:1157-1167.

35. Walerych D, Napoli M, Collavin L, Del Sal G. The rebel angel: mutant p53 as the driving oncogene in breast cancer. Carcinogenesis. 2012; 33:2007-2017.
36. Walerych D, Lisek K, Del Sal D. Mutant p53: One, No One, and One Hundred Thousend. Front Oncol. 2015; 5:289.

37. Galanos P, Vougas K, Walter D, Polyzos A, MayaMendoza A, Haagensen EJ, Kokkalis A, Roumelioti FM, Gagos S, Tzetis M, Canovas B, Igea A, Ahuja AK, et al. Chronic p53-independent p21 expression causes genomic instability by deregulating replication licensing. Nat Cell Biol. 2016; 18:777-789.

38. Cancer Genome Atlas Network. Comprehensive molecular portraits of human breast tumours. Nature. 2012; 490:61-70.

39. Kitamura T, Qian BZ, Pollard JW. Immune cell promotion of metastasis. Nat Rev Immunol. 2015; 15:73-86.

40. Lakhani SR, Ellis IO, Schnitt SJ, Tan PH, van de Vijver MJ. WHO Classification of Tumours of the Breast. 4th. Lyon: IARC Press; 2012.

41. Elston CW, Ellis IO. Pathological prognostic factors in breast cancer. I. The value of histological grade in breast cancer: experience from a large study with long-term follow-up. Histopathology. 1991:19:403-410.

42. Wolff AC, Hammond ME, Schwartz JN, Hagerty KL, Allred DC, Cote RJ, Dowsett M, Fitzgibbons PL, Hanna WM, Langer A, McShane LM, Paik S, Pegram MD, et al. American Society of Clinical Oncology /College of American Pathologists guideline recommondations for human epidermal growth factor receptor 2 testing in breast cancer. Arch Pathol Lab Med. 2007:131:18-43.

43. Untch M, Gerber B, Harbeck N, Jackisch C, Marschner N, Möbus V, von Minckwitz G, Loibl S, Beckmann MW, Blohmer JU, Costa SD, Decker T, Diel I, et al. 13th St. Gallen international breast cancer conference 2013: primary therapy of early breast cancer evidence, controversies, consensus - opinion of a german team experts. Breast Care. 2013:8:221-229.

44. Dimri GP, Lee X, Basile G, Acosta M, Scott G, Roskelley C, Medrano EE, Linskens M, Rubelj I, Pereira-Smith OM, Peacocke M, Campisi J. A biomarker that identifies senescent human cells in vitro and in aging skin in vivo. Proc Natl Acad Sci USA. 1995; 92:9363-9367. 